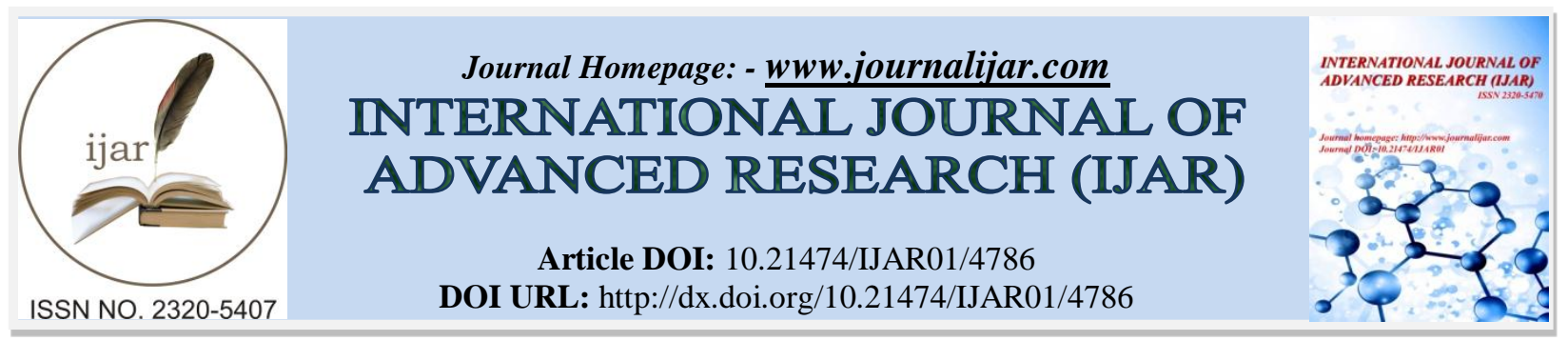

RESEARCH ARTICLE

\title{
THE IMPACT OF RS662 GENOTYPING ON THE SERUM ACTIVITY OF THE PARAOXONASE -1 ENZYME IN IRAQI PATIENTS WITH CARDIOVASCULAR DISEASES.
}

Raya Kamal Mohammed Salih ${ }^{1}$, Najat Abdulrazzaq Hasan ${ }^{2}$ and Rafid Bashir Hashim ${ }^{3}$.

1. B. SC., Higher Diploma, Ministry of Health, Kimadia, Baghdad, Iraq.

2. Professor, $\mathrm{PhD}$, Clinical Biochemistry, College of Medicine, Al Nahrain University, Baghdad, Iraq.

3. Lecturer, MB ChB - FIBMS, Consultant Cardiologist, Medicine-Cardiology ,College of Medicine, , Al Nahrain University, Baghdad, Iraq.

\section{Manuscript Info}

\section{Manuscript History}

Received: 8 May 2017

Final Accepted: 10 June 2017

Published: July 2017

Key words:-

Cardiovascular diseases, PON1

activity, PON1Q192R ( re662)

polymorphism, Lipid profile

\section{Abstract}

Background: Cardiovascular diseases (CVDs) are diseases that affect the heart or vessels. Coronary artery disease (CAD) and peripheral (PAD) are types of CVD. PON1 is a HDL-associated lipolactonase is considered to be atheroprotective by preventing LDL and cell membranes oxidation. A common polymorphism due to an amino acid substitution (Glutamine $\rightarrow$ Arginine) at codon 192 is considered to be a major determinant of variation in serum PON1 activity. Recent studies have suggested that the PON1192 polymorphism is an independent risk factor for CVD

Objectives: The effect of the PON1 activity and PON1 Q192R (rs662) polymorphisms on the CVD include patients with PAD and CAD.

Subject and Methods: This case control study consisted of 180 subjects were divided into 100 patients with CVD (50 patients with PAD and 50 patients with CAD), and 80 healthy controls. Serum levels for lipid profile and PON1 enzyme were measured by spectrophotometer using paraoxon as a substrate. The genetic polymorphism of PON1 was detected by TaqMan-based allele discrimination RT- PCR

Results: The means \pm SEM of serum PON1 activity were highly significantly decreased in PAD and CAD as compared to control group. The heterozygote (Q192R) genotype of PON1 polymorphism is abundant among all of the studied groups (68\% for PAD, 56\% for CAD and 65\% for control, respectively). The CAD patients carry the high risk RR genotyping (odd ratio of 2.69, with the confidence interval of (1.12-6.47; $\mathrm{p}=0.02)$. The PAD who carry the RR genotype have a risk ratio 1.57 at confidence interval of 0.61- 4.02.

Conclusion: Reduction of PON1 activity is one of the risk factor of development of CVD . Patients who carry the RR genotyping were at high risk to develop CVD. Our results indicate that controversial relationships regarding the PON1 rs $662(\mathrm{Q} 192 \mathrm{R})$ polymorphism and CVD. Serum PON1 activity is more informative than the PON1 genotype in evaluating the severity and extent of cardiovascular disease in Iraqi patients. 


\section{Introduction:-}

Cardiovascular diseases (CVDs) are diseases that affect the heart or blood vessels, which include Coronary artery disease (CAD), Stroke, Peripheral arterial disease (PAD) and aortic disease (WHO,2015). Atherosclerosis is the primary cause of the development of cardiovascular diseases that account for the majority of fatal illnesses in developed countries and illness worldwide (Roth et al., 2015). Genetic is fixed factor to CVD (WHO, 2012).

The high density lipoprotein (HDL) has a central role in the inhibition of atherosclerosis development due to its antiatherogenic properties. The HDL is crucial for the reverse cholesterol transport (Cohen et al., 2016), the process by which cholesterol is transferred from peripheral tissues, including the arterial wall, to the liver for excretion in the bile. The beneficial functions of HDL could be played by enzymes and proteins associated with this lipoprotein, such as cholesteryl ester transfer protein (CETP) and PON1 enzyme. In addition to playing a pivotal role in reverse cholesterol transport, The cardio protective role of the small dense HDL is done to its ability to accept cholesterol from foam cells by ATP binding cassette transporter A1 (ABCA1) ( Du ,2015). The HDL actually metabolizes lipid hydroperoxides preventing their accumulation, consequently impeding the atherogenic structural modification of LDL (Mackness et al., 1991).This effect is related to enzymatic activity associated with HDL, and not chainbreaking antioxidants or transition metal chelation (Mackness et al., 1993; Durrington et al., 2001).

Human serum paraoxonase-1 (PON1: EC 3.1.8.1) is a 354 amino acid glycoprotein with a molecular weight of 43 KD (Adkins et al.,1991). PON1 is synthesized in the liver and secreted into the blood, where it associates exclusively with high-density lipoprotein (HDL) ( Mackness et al.,1996). PON1 is named for its ability to hydrolyze organophosphates such as paraoxon (Aldridge,1953). The gene for PON1 is located between q21.3 and q22.1 on the long arm of chromosome 7 in humans (Harel et al., 2004). PON1 is the first discovered member of the paraoxonase (PON) multi-gene family which comprises 3 members, PON1, PON2 and PON3, the genes for which are located adjacent to each other (Primo-Parma et al., 1996).

The PON1 have significant anti-oxidative and anti-inflammatory properties through its enzymatic lactonase, peroxidase and esterase activities (Précourt et al., 2011). PON1 is a HDL-associated lipolactonase is considered to be atheroprotective by preventing LDL and cell membranes oxidation (Altuner, 2011; Mackness, 2014). PON1 a major antioxidant, is regarded as a cardiovascular protective factor and its activity is reduced in patients with CVD (Deakin, et al., 2004 and Kowalska et al., 2015).

PON1 may slow the evolution of the early stages of atherosclerosis, and may participate in the reduction of cardiovascular risk through its activities, depending on genetic and environmental factors (Rainwater et al., 2009).

The SNP rs662 present in the coding region, and causes exchange of amino acid from glutamine (Q) to arginine (R) at codon 192 (Q192R), the exchange of codon CAA to CGA in exon six of PON1gene determines the isoforms of the PON1 enzyme which differ greatly in the rate of hydrolysis of some substrates. Paraoxon is hydrolyzed at faster rate by the $192 \mathrm{R}$ isoform compared to the Q192, but some organophosphates and lactones are hydrolyzed at greater rate by Q192 (Billecke et al.,2000; Davies et al., 1996 ). The R isoform of the enzyme has higher lactonase activity and increased antiatherogenic potential (Gaidukov et al., 2006). The polymorphism Q192R (rs662) leads to different PON1enzymatic activity behavior dependent of the isoenzyme that is present (Costa et al.,2003).

\section{Material and Methods:-}

\section{Subjects:-}

This research was a case-control study .It was conducted in Coronary Care Unit (CCU) of Gazi Al-Harery Hospital for Specialized Surgery in Iraqi Center for Heart Diseases, Ibn Al-Betar Hospital of Cardiovascular Diseases, and Al-Immamain Al-Kadhimain Medical City. The genetic practical part of this study was conducted at Department of Chemistry and Biochemistry Laboratory, and study protocol was approved by Ethical Committee of College of Medicine, Al-Nahrain University, Baghdad, Iraq. In this study 180 subjects were examined during the period from February 2016 to October 2016. Out of these 180 subject 100 patients were with CVD (50 patients with CAD and 50 patients with PAD), the other 80 subjects were healthy controls. The ages of all subjects were ranging from 35 to 65 years. 


\section{Coronary artery disease group $(\mathrm{CAD}):-$}

Included 50 patients with unstable angina (UA) based on the defined electrocardiographic changes and non elevated cardiac enzymes such as CK-MB and Troponin, or angiographic evidence of at least 50\% stenosis of one or more epicardial vessels.

\section{Peripheral artery disease group (PAD):-}

Included 50 patients were caused by atherosclerosis that leads to stenosis (narrowing) or blockage in the major vessels supplying the lower extremities. The ankle to brachial pressure index (ABPI) is measured using a sphygmomanometer .

All patients were diagnosed by Senior Cardiologist and underwent clinical examination, ECG, Eco-cardiograph and angiographic study.

\section{Control groups:-}

Include 80 healthy individuals with no history of diabetes, hypertensive, hyperlipidemia or coronary vascular disease.

\section{Patients Exclusion criteria:-}

Patients with renal failure or nephropathy, with hepatic diseases, and patients on anti-depressant and anti-psychotic drug

\section{Blood sample Collection:-}

About six milliliters of venous blood was taken from each participant, then was divided as following: $4 \mathrm{ml}$ of blood were put into serum separating tube (SST) and left to clot for $30 \mathrm{~min}$ at room temperature then were centrifuged at $4000 \mathrm{rpm}$ for $10 \mathrm{~min}$. The serum separated was distributed in small aliquots and stored at $-80^{\circ} \mathrm{C}$ for the evaluation of PON1 enzyme activity and analysis of , total cholesterol(TC), high density lipoprotein cholesterol (HDL-C), low density lipoprotein (LDL-C), triglyceride(TG), and $2 \mathrm{ml}$ of the blood was put into two separated EDTA containing tubes for the assay of DNA extraction and genotyping for the detection of the Q192 R polymorphism of PON1 (rs662 ) gene using RT- PCR technique.

\section{Determination of serum PON1 enzyme Activity:-}

Serum PON1 activity was measured using a procedure modified from the method of Krisch (1968). It depends on monitoring the liberation of p- nitrophenol upon PON1 enzymatic hydrolysis of paraoxon (Sigma-Aldrich ,USA) and the absorbance was continuously monitored for $6 \mathrm{~min}$ at $405 \mathrm{~nm}$ against paraoxonase substrate reagent solution which was used as a reagent blank for the correction of not enzymatic hydrolysis of paraoxon. The reaction is stable up to 5 minute. A molar extinction coefficient of $18.05 \times 10^{3}$ was used for the calculations of PON1 activity (Biggs,1954), and units of enzyme activity were expressed as micromoles of paraoxon hydrolyzed per minute.The paraoxonase assay contained $760 \mu \mathrm{l}$ of assay buffer $(0.132 \mathrm{M}$ Tris- $\mathrm{HCl}, \mathrm{pH}=8.5,1.32 \mathrm{mM} \mathrm{CaCl}$, and $2.63 \mathrm{M}$ $\mathrm{NaCl}, 40 \mu \mathrm{l}$ of fresh serum, and $200 \mu 1$ of $6 \mathrm{mM}$ freshly prepared paraoxon substrate solution. A stock substrate solution of $120 \mathrm{mM}$ paraoxon in acetone was stable for approximately $3 \mathrm{wk}$. The stock solution was diluted 1:20 with $50 \mathrm{mM}$ Tris-HC1 $(\mathrm{pH}=8.5)$ for each set of assays. The assay at $37 \mathrm{C}$ was initiated by the addition of the substrate solution, and the absorbance was continuously monitored at $405 \mathrm{~nm}$.

\section{Determination of serum lipids profile:-}

Total cholesterol (TC) and high density lipoprotein cholesterol (HDL-C) were determined by using CHOD-PAP method using kit from (Randox, UK), triglycerides (TG) was measured by the enzymatic GPO-PAP method using kit from (Randox, UK). LDL was estimated using Friedwald formula: LDL $=\mathrm{TC}-(\mathrm{HDL}+\mathrm{TG} / 2.2) \mathrm{mmol} / \mathrm{l}$ (Friedewald et al.,1972).

\section{Genotyping of PON1 Q192R:-}

Genomic DNA was isolated from whole peripheral blood using DNA extraction kit (Geneaid,Taiwan) according to the manufacturer's protocol. Q192R polymorphisms of the PON1 (rs662) gene were determined by using TaqManbased allele discrimination real time PCR based on the following

Primers :5- ACCTGAGCACTTTTATGG -3 forward primer and 5- ATCAAA TCCT TCTG CCAC -3 reverse primer were designed by ( Alpha DNA,USA); and 
Probes:GoTaq ${ }^{\circledR P r o b e}$ qPCR Master Mix :- PON1probe-1: Cy5-CCCCTACTTACAATCCTGGGAGA-BHQ2 (wild), and PON1 probe -2: Cy3-CCCCTACTTACGATCCTGGGAGA-BHQ2 (mutant).

were designed by (promega, USA). Genotyping assays were performed on Aligant RT- PCR (Stratagene 3005xp USA).

The SNP rs 662 at exon 6 of the PON1 gene causes change in the base sequenced (missense) at the codon number 672 from CAA to CGA at mRNA. This base shift result in replacement of the amino acid in the sequence at position 192 (Glutamine to Arginine) of the resulting polypeptide chain of the PON1 enzyme (Q192R).

\section{Statistical Analyses:-}

The data were analyzed using SPSS (version 23.0) software for windows (USA). Comparisons between groups were performed using one-way ANOVA for multiple comparisons. Chi- square test was performed for Q192R polymorphism in PON1(rs662) gene to determine if the studied samples demonstrated Hardy Weinberg equilibrium (H-WE) . Logistic regression was used to calculate odd ratio (ORs) at confidence interval (CI) of 95\%. All results were interpreted at an alpha level of 0.05 .

\section{Results:-}

Results of general characteristics and study biochemical and clinical parameters:-

The clinical characteristics of the study groups are shown in table (1)

The mean \pm SEM of Age (year) for patients groups (PAD and CAD) and control group were 59.60 \pm 0.63 year, 53.94 \pm 0.92 year, and $54.71 \pm 0.92$ years respectively. The mean age of the PAD patients group were significantly higher $(P<0.001)$ than control and CAD groups whereas the mean age of CAD patient group were no significantly different $(P=0.55)$ when compared to those of PAD group. The mean \pm SEM of BMI $\left(\mathrm{Kg} / \mathrm{m}^{2}\right)$, systolic blood pressure $(\mathrm{mmHg})$, and diastolic blood pressure $(\mathrm{mmHg})$ for PAD patients $\left(29.37 \pm 0.30 \mathrm{~kg} / \mathrm{m}^{2}, 143.50 \pm 0.93 \mathrm{mmHg}\right.$, $92.70 \pm 1.99 \mathrm{mmHg}$, respectively), CAD patients $\left(30.32 \pm 0.43 \mathrm{~kg} / \mathrm{m}^{2}, 143.22 \pm 0.94 \mathrm{mmHg}, 92.68 \pm\right.$ $0.77 \mathrm{mmHg}$,respectivly) and control group were $\left(25.59 \pm 0.22 \mathrm{~kg} / \mathrm{m}^{2}, 125.79 \pm 0.82 \mathrm{mmHg}, 82.25 \pm 0.38 \mathrm{mmHg}\right.$, respectively).

Both PAD and CAD patient groups have high significant increases $(P<0.001)$ in mean of BMI $\left(\mathrm{Kg} / \mathrm{m}^{2}\right)$, systolic blood pressure $(\mathrm{mmHg})$ and diastolic blood pressure $(\mathrm{mmHg})$ when compared with control group. Yet, there was no significant increase in the mean BMI $(P=0.07)$ in CAD as compared to that of the PAD group.

Table 1:- Descriptive statistics of biochemical \& clinical parameters in the study groups

\begin{tabular}{|c|c|c|c|}
\hline Parameters & PAD $(n=50)$ & CAD $(n=50)$ & Control $(n=80)$ \\
\hline Age (year) & $\begin{array}{c}59.60 \pm^{\mathbf{\Lambda} \mathrm{a}^{* * *} \boldsymbol{\Delta} \mathbf{b}^{* * * *}} \\
0.63\end{array}$ & $\begin{array}{c}53.94 \pm \\
0.92\end{array}$ & $\begin{array}{c}54.71 \pm \\
0.92\end{array}$ \\
\hline BMI $\left(\mathrm{kg} / \mathrm{m}^{2}\right)$ & $\begin{array}{c}29.37 \pm^{\mathbf{\Delta}^{* * * *}} \\
0.30\end{array}$ & $\begin{array}{c}30.32 \pm^{\mathbf{\Lambda} \mathrm{a}^{* * * *}} \\
0.43\end{array}$ & $\begin{array}{c}25.59 \pm \\
0.22\end{array}$ \\
\hline SBP $(\mathrm{mmHg})$ & $\begin{array}{c}143.50 \pm^{\mathbf{\Lambda} \mathrm{a}^{* * * *}} \\
0.93\end{array}$ & $\begin{array}{c}143.22 \pm^{\mathbf{\Lambda} \mathrm{a}^{* * *}} \\
0.94\end{array}$ & $\begin{array}{c}125.79 \pm \\
0.82\end{array}$ \\
\hline DBP (mmHg) & $\begin{array}{c}92.70 \pm^{\mathbf{\Lambda}}{ }^{* * * *} \\
1.99\end{array}$ & $\begin{array}{c}92.68 \pm \pm^{\mathbf{\Delta} \mathrm{a} * * *} \\
0.77\end{array}$ & $\begin{array}{c}82.25 \pm \\
0.38\end{array}$ \\
\hline $\mathrm{TC}(\mathrm{mmol} / \mathrm{l})$ & $\begin{array}{c}4.49 \pm \\
0.10\end{array}$ & $\begin{array}{c}4.43 \pm^{\boldsymbol{\top}} \\
0.09\end{array}$ & $\begin{array}{c}4.44 \pm \\
0.04\end{array}$ \\
\hline HDL-C (mmol/l) & $\begin{array}{c}0.81 \pm{ }^{\nabla a^{* * *} \nabla} b^{*} \\
0.03\end{array}$ & $\begin{array}{c}0.93 \pm^{\mathbf{\nabla}^{a * * *}} \\
0.35\end{array}$ & $\begin{array}{c}1.28 \pm \\
0.02\end{array}$ \\
\hline $\mathrm{TG}(\mathrm{mmol} / \mathrm{l})$ & $\begin{array}{c}1.43 \pm^{\mathbf{\Lambda}}{ }^{a * * *} \\
0.06\end{array}$ & $\begin{array}{c}1.36 \pm^{\mathbf{\Lambda} \mathrm{a}^{* * * *}} \\
0.04\end{array}$ & $\begin{array}{l}1.12 \pm \\
0.03\end{array}$ \\
\hline VLDL-C( mmol/l) & $\begin{array}{c}0.65 \pm^{\mathbf{\Lambda} \mathrm{a}^{* * * *}} \\
0.03\end{array}$ & $\begin{array}{c}0.62 \pm{ }^{\mathbf{\Delta} \mathrm{a}^{* * * *}} \\
0.02\end{array}$ & $\begin{array}{l}0.51 \pm \\
0.01\end{array}$ \\
\hline LDL-C( $\mathrm{mmol} / \mathrm{l})$ & $\begin{array}{c}3.04 \pm^{\mathbf{\Lambda} \mathrm{a}^{* * *}} \\
0.09\end{array}$ & $\begin{array}{c}2.88 \pm^{\mathbf{\Lambda} \mathrm{a}^{*}} \\
0.09\end{array}$ & $\begin{array}{l}2.66 \pm \\
0.05\end{array}$ \\
\hline TC/HDL-C & $\begin{array}{c}6.17 \pm^{\mathbf{\Lambda} \mathrm{a}^{* * *}} \\
0.36\end{array}$ & $\begin{array}{c}5.28 \pm^{\mathbf{\Lambda} \mathrm{a}^{* * *}} \\
0.34\end{array}$ & $\begin{array}{l}3.59 \pm \\
0.08\end{array}$ \\
\hline
\end{tabular}




\begin{tabular}{|c|c|c|c|}
\hline PON1 activity & $42.69 \pm \mathbf{\nabla}^{\mathrm{a} * *} \mathbf{\nabla} \mathrm{b} *$ & $48.96 \pm \mathbf{\nabla}^{* * *}$ & $85.48 \pm$ \\
$(\mathrm{U} / \mathrm{ml})$ & 2.06 & 1.95 & 2.16 \\
\hline
\end{tabular}

PAD: Peripheral artery disease group; CAD : Coronary artery disease group; Control group; SEM: standard error of the mean $\mathbf{a}=$ ANOVA test between PAD or CAD patients group versus control group: ${ }^{\mathbf{7} \text { or } \mathbf{\Delta}}=$ significant decrease or increase $^{* * * *}:(\mathrm{P}<0.001){ }^{* *}:(\mathrm{P}<0.01)$; ${ }^{*}: \mathrm{P}<0.05 . \mathbf{b}=$ ANOVA test between PAD versus CAD patients groups: ${ }^{\mathbf{\nabla}}$ or $\mathbf{\Lambda}=$ significant decrease or increase ${ }^{* * *}:(\mathrm{P}<0.001) ;^{* *}:(\mathrm{P}<0.01)$; ${ }^{*}: \mathrm{P}<0.05$.

The mean \pm SEM of serum lipid profile (TC, HDL-C, VLDL-C, LDL-C) and atherogenic index (TC/HDL-C ratio), are listed in table (1). Statistical analysis revealed no significant difference in the mean values of TC between patient groups and control group $(P>0.05)$ and there were highly significant decrease in the mean of HDL in PAD $(0.81$ $\pm 0.03 \mathrm{mmol} / \mathrm{l})$ and $\mathrm{CAD}(0.93 \pm .035 \mathrm{mmol} / \mathrm{l})$ as compared to the control group mean values $(1.28 \pm 0.02 \mathrm{mmol} / \mathrm{l}$, $P<0.001)$.

The means of serum TG and VLDL-C concentration were highly significant increased $(P<0.001)$ in PAD $(1.43 \pm$ $0.06 \mathrm{mmol} / \mathrm{l}, 0.65 \pm 0.03 \mathrm{mmol} / \mathrm{l})$ and in CAD ( $1.36 \pm 0.04 \mathrm{mmol} / \mathrm{l}, 0.62 \pm 0.02 \mathrm{mmol} / \mathrm{l})$ as compared to those of the control group $(1.12 \pm 0.03 \mathrm{mmol} / \mathrm{l}, 0.51 \pm 0.01 \mathrm{mmol} / \mathrm{l})$. The TC/HDL-C concentration were highly significantly increased in both patient groups but LDL-C is significantly elevated only in PAD group $(3.04 \pm 0.094 \mathrm{mmol} / \mathrm{l}, P$ $<0.001)$ but is near significantly increased in CAD patients $(2.88 \pm 0.098 \mathrm{mmol} / \mathrm{l}, P=0.057)$ as compared to control group.

The means of serum PON1 activity were highly significantly decreased $(P<0.001)$ in PAD $(42.69 \pm 2.06 \mathrm{U} / \mathrm{ml})$ and CAD $(48.96 \pm 1.95 \mathrm{U} / \mathrm{ml})$ as compared to mean of PON1 of the control group $(85.48 \pm 2.16 \mathrm{U} / \mathrm{ml})$. Moreover, the PON1 activity were decreased in PAD group as compared to those of the CAD group $(P=0.03)$.

\section{Results of Molecular Analyses:-}

The Hardy-Weinberg distributions of PON1 genotypes Q192R among all of the patient and control groups are represented in table (2) and figure (1). Using $\mathrm{X}^{2}$ test, the highest frequency of PON1 genotype Q192R in patients and control groups were (68\% for PAD ,56\% for CAD, and $56 \%$ for control respectively) .Hardy Weinberg equilibrium (H-WE) delineated that highest allele frequency is $192 \mathrm{R}$ in both PAD and CAD groups (0.54,0.58, respectively), Whereas, the 192Q allele is of highest percentage in the control group as compared to the same group distribution frequency of 192R allele (0.54).

Table 2:-Distribution of genotypes and alleles frequency of the PON1 rs662 (Q192R) polymorphism among different studied groups

\begin{tabular}{|c|c|c|c|c|c|}
\hline \multirow{2}{*}{ Groups } & \multicolumn{3}{|c|}{ Genotypes frequency } & \multicolumn{2}{c|}{ Alleles frequency } \\
\cline { 2 - 6 } & Q192Q, $(\%)$ & Q192R, $(\%)$ & R192R n(\%) & $192 \mathrm{Q}$ & $192 \mathrm{R}$ \\
\hline PAD $(\mathrm{n}=50)$ & $6(12 \%)$ & $34(68 \%)$ & $10(20 \%)$ & 0.46 & 0.54 \\
\hline CAD $(\mathrm{n}=50)$ & $7(14 \%)$ & $28(56 \%)$ & $15(30 \%)$ & 0.42 & 0.58 \\
\hline Control(n=80) & $17(21.3 \%)$ & $52(65 \%)$ & $11(13.7 \%)$ & 0.54 & 0.46 \\
\hline Chi square test $: P=0.161$
\end{tabular}




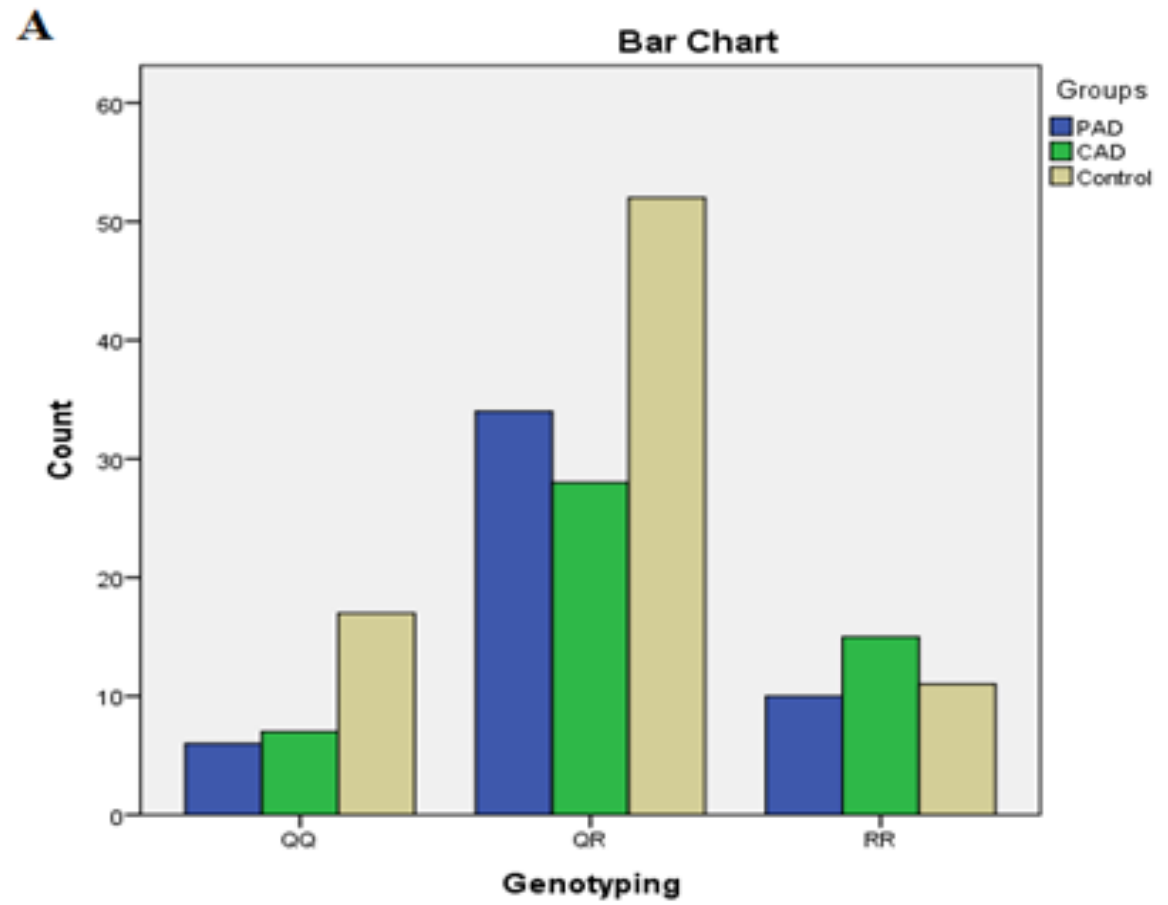

Figure 1:- The distribution of studied samples among different groups according to Genotypes

Table 3:- The Odds ratio, 95\% confidence interval of the PON1 rs662 (Q192 R) polymorphism in PAD and CAD groups

\begin{tabular}{|c|c|c|c|c|}
\hline $\begin{array}{c}\text { Genotypes } \\
\text { Q192R }\end{array}$ & $\begin{array}{c}\text { PAD } \\
\text { Odds Ratio(95\%CI) }\end{array}$ & P-Value & $\begin{array}{c}\text { CAD } \\
\text { Odds Ratio(95\%CI) }\end{array}$ & P-Value \\
\hline QQ & Reference & & Reference & \\
\hline QR & $1.14(0.54-2.43)$ & 0.72 & $0.69(0.33-1.41)$ & 0.30 \\
\hline RR & $1.57(0.61-4.02)$ & 0.34 & $2.69(1.12-6.47)$ & 0.02 \\
\hline QR+RR & $0.51(0.19-1.39)$ & 0.18 & $0.60(0.23-1.58)$ & 0.30 \\
\hline
\end{tabular}

The odd ratio, 95\% confidence intervals between PAD and CAD groups who carry the RR genotyping were at high risk (odd ratio of 2.69) with the confidence interval of 1.12-6.47( $\mathrm{p}=0.02)$ to develop CAD as compared to PAD individual, who carry other genotypes. The mean odd ratio 1.57 was found in PAD who carry the RR genotype at confidence interval of 0.61- 4.02. The combination of the abnormal genotypes (QR+RR) displayed higher frequency in patients with PAD 88\% (44/50) and 86\% (43/50) in CAD as compared to 78\% (63/80) in the control group. Yet, the combined genotypes showed no significant change in the odd ratio in both patient groups $(P>0.05)$.

Table 4:- The distribution of PON1 enzyme activity among studied group according to genotyping of the PON1 rs662 (Q192R) polymorphism

\begin{tabular}{|c|c|c|c|}
\hline Genotypes & \multicolumn{3}{|c|}{ PON1enzyme activity(U/ml) } \\
\hline Q192R & $\begin{array}{l}\text { PDA } \\
(\mathrm{n}=50)\end{array}$ & $\begin{array}{l}\text { CAD } \\
(\mathrm{n}=50)\end{array}$ & $\begin{array}{l}\text { Control } \\
(\mathrm{n}=80)\end{array}$ \\
\hline $\mathrm{QQ}(\mathrm{n}=30)$ & $\begin{array}{c}(\mathrm{n}=6) \\
38.43 \pm 6.42^{\mathrm{a}}{ }^{* * * * b *}\end{array}$ & $\begin{array}{c}(\mathrm{n}=7) \\
43.49 \pm 4.24^{\text {av****}}\end{array}$ & $\begin{array}{c}(\mathrm{n}=17) \\
90.86 \pm 4.57\end{array}$ \\
\hline $\mathrm{QR}(\mathrm{n}=114)$ & $\begin{array}{c}(n=34) \\
42.39 \pm 2.49^{a-* * *} b *\end{array}$ & $\begin{array}{c}(\mathrm{n}=28) \\
49.71 \pm 2.79^{\mathrm{a} a * *}\end{array}$ & $\begin{array}{c}(n=52) \\
84.67 \pm 2.82\end{array}$ \\
\hline $\mathrm{RR}(\mathrm{n}=36)$ & $\begin{array}{c}(n=10) \\
46.31 \pm 4.68^{a * * *}\end{array}$ & $\begin{array}{c}(\mathrm{n}=15) \\
50.11 \pm 3.39^{\mathrm{a} a * *}\end{array}$ & $\begin{array}{c}(n=11) \\
80.95 \pm 4.09\end{array}$ \\
\hline
\end{tabular}


PAD: Peripheral artery disease group; CAD: Coronary artery disease group; Control group $\mathbf{a}=$ ANOVA test between PAD or CAD patients group versus control group: ${ }^{* * *}=(P<0.001) ; ;^{* *}:(P<0.01) ;{ }^{*}: P<0.05 . \mathbf{b}=$ ANOVA test between PAD versus CAD patients groups: ${ }^{* * *}:(P<0.001) ;{ }^{* *}:$ $(P<0.01) ;{ }^{*}: P<0.05$.

Table (4) shows the distribution of serum PON1 enzyme activities among PAD, CAD, and control groups according to genotyping of the PON1rs662 (Q192R) polymorphism. The serum PON1 enzyme activity were significantly reduced $(P<0.001)$ in PAD and CAD patients who carry QQ (wild) genotype as compared with QQ genotyping of the control group.

Patients with PAD and CAD group who were heterozygote for PON1 activity (Q192R) were having significantly decreased PON1 activity $(P<0.001)$ as compared to same genotype in the control group. Highest PON1 enzyme activity was reported in the control group with RR genotype as compared to PAD and CAD patients carrying the same genotype $(P<0.001)$. Furthermore, the means PON1 activities were decreased in PAD patients who carries QQ $(\mathrm{P}=0.02), \mathrm{QR}(\mathrm{P}=0.04)$, and $\mathrm{RR}(\mathrm{P}=0.07)$ genotypes as compared to same genotype carrier in the CAD group.

\section{Discussion:-}

The means of age, BMI, systolic and diastolic blood pressure were significantly high in both PAD and CAD patient groups when compared to control group. These results are different from those of Paapstel et al.(2016) who reported no difference in age and mean diastolic blood pressure in PAD group but the CAD patients had significantly higher BMI levels than the PAD and the control group.

This study displayed a disturbance in the lipid profile as represented by highly significant decrease in the means of HDL-C, increase in TG, VLDL-C and TC/HDL-C in PAD and CAD . The mean LDL-C mmol/l concentration was highly significant increase in PAD patient group $(P<0.001)$ but it is significantly increased in CAD patient group. Ivanova et al.(2015) reported that individuals with high CVD risk have elevated amounts of circulating low-density lipoprotein (LDL) and decreased percentages of high-density lipoprotein (HDL).

The major source of cholesterol and the lipids is LDL that contributes to the development of the atherosclerotic plaque, whereas no atherogenic HDL and its concentrations were inversely correlated with the risk of CVD development. On the contrary, Paapstel et al.(2016) revealed no significant changes in HDL-C,TC, LDL-C in patients with PAD.

High TC/HDL-C is considered predictor to CVD, As TC/HDL-C ratio is considered a more sensitive and specific index of cardiovascular risk than total cholesterol, the Canadian working group has chosen this lipid ratio as a secondary goal of therapy (Genest et al.,2003).

High-density lipoprotein cholesterol is considered the best biochemical predictor of PAD. Other risk factors of premature PAD include smoking, diabetes, and hypertension, high circulating levels of cholesterol, TG, and homocystein. Whereas, high blood fibrinogen concentration is a thrombosis risk factor (Dell'Omo et al. ,2014)

Determination of serum PON1 activities in PAD and CAD groups revealed highly significant loss of PON1 activities in these patients. Some authors have evidenced that PON1 enzyme activity is lower in subjects with significant coronary artery disease, and that there is a significant relationship between PON1 activity and coronary atherosclerosis determined by coronary angiography (Granér et al,2006). The PON1 activity in different CAD groups was significantly lower than those of non-CAD counter group and the decreases of PON1 activity were especially evident in severe CAD group compared with those with mild or moderate CAD. This finding reflects a close relationship with the risk of CAD (Lakshmy et al., 2010).

PONs enzymes possess numerous atheroprotective properties, which include anti-oxidant activity, antiinflammatory action, anti-apoptosis, anti-thrombosis, and anti-adhesion, also it maintains HDL function, and promotes cholesterol efflux (Chistiakov et al., 2017).

These disorders are likely to contribute to increased plaque burden, plaque instability, and greater complexity of vascular disease (Thiruvoipati et al., 2015). Moreover, the increase in the atherogenic index (TC/HDL-C) is reported to be the best biochemical predictor of PAD, according to the Trans-Atlantic Inter-Society Consensus Document on Management of Peripheral Arterial Disease (TASMCII) (Norgren et al.,2007). Surprisingly, they recorded that the prevalence of PAD in rural black population of Uganda was higher in normotensives and in those with a normal 
BMI (Kumar et al., 2007). This study revealed a strong association of PON1 activity with LDL-C in the studied groups.

Genetic variations have a major impact on PON1 catalytic activity and amino acid 192 is an important active-site of the enzyme also , was anchoring on HDL surface (Lawlor et al.,2004).

The highest PON1 genotype frequency observed in the studied patients (PAD and CAD) and control groups is the heterozygote (Q192R) genotype $(68 \%, 56 \%$ and $65 \%$, respectively) .This genotype is in the Hardy-Weinberg distribution.

Patients who carry the RR genotyping were at high risk ( odd ratio of 2.69) with the confidence interval of 1.12$6.47(\mathrm{p}=0.02)$ to develop CAD as compared to PAD individual, who carry other genotypes . The mean odd ratio 1.57 was found in PAD who carry the RR genotype at confidence interval of 0.61-4.02. The combination of the abnormal genotypes $(\mathrm{QR}+\mathrm{RR})$ displayed higher frequency in patients with PAD 88\% . On the contrary, Lebedy et al. (2014) reported that the frequency of $\mathrm{QQ}$ is the highest in the control group and the patients had a higher frequency of $\mathrm{AB}(\mathrm{QR})$ and $\mathrm{BB}(\mathrm{RR})$ genotype as compared to controls

The mean serum PON1 activity were significantly reduced $(P<0.001)$ in PAD and CAD patients who carry QQ (wild) genotype as compared with QQ genotyping of the control group. Serum paraoxonase activity is higher in RR genotype carrier and is the lowest in QQ genotype. Paraoxonase QR variants showed intermediate activities between respective homozygous. Other scientist reported an association of the PON1192RR genotype with low HDL-C levels and a higher level of LDL-cholesterol (Rozek et al.,.2005; Blatter et al.,2006).

The PON1Q192R genotype has an impact on the hydrolytic activity of PON1 toward the substrate paraoxone (Scherrer et al., 2015). The QQ genotype, with low PON1 activity, may be adequate to prevent lipid peroxidation in young or elderly subjects without atherosclerosis. However, the low PON1-activity QQ genotype may have its antioxidant capacity surpass with advanced age, which probably compromises the PON1 function in concomitant with CHD (Sentí et al., 2001).

The highest allele frequency is $\mathrm{R}$ in patients within the $\operatorname{PAD}$ and $\operatorname{CAD}(0.54,0.58$, respectively) groups whereas, the $\mathrm{Q}$ allele is of highest percentage in the control group. Yet, higher frequencies of Q allozymes $(0.78)$ was previously reported by Zargari et al. (2016)

Hernández-Díaz et al. (2016) who revealed that the 192Q allele carriers are at high risk to develop CAD. On the other hand, in another study, Bounafaa et al. (2015) reported that the PON1 R allele is abundant in CHD patients, indicating that the PON1192 polymorphism may be a risk factor for atherosclerosis.

The increased risk of CVD in RR genotype carrier could be attributed to an increased susceptibility of LDL to oxidation, and an alteration in function and reduced the antioxidant effect of HDL (Dell'Omo et al., 2014), the common PON1 192R allele may be a genetic risk factor for atherogenesis by inducing chronic low-grade inflammation (Luersen et al.,2011). Low serum PON1 activity alleles are associated with a decreased transfer of lipids between lipoprotein particles (Ombres et al. 1998).Conversely, several other studies inconsistent results regarding the link between PON1 Q192R polymorphism and CVD (Kallel et al., 2010). The RR genotype was more frequent in patients with CVD and was independently associated with the disease risk. In this context, the Iraqi population presents controversial relationships regarding the Q192R SNP and cardiovascular disease.

The 192 Q PON1 allozyme was shown to bind to the HDL particle with 3-fold lower affinity than the $192 \mathrm{R}$ allozyme, consequently showing lower stability, and lipolactonase activity, and a modulatory effect on macrophage cholesterol efflux .Both evaluated paraoxonase activities were found the greatest in the group of patients with $192 \mathrm{Q}$ allozyme and this fact should be helpful to explain the high level of LDL cholesterol in patients with $192 \mathrm{R}$ allozyme (Kasprzak et al., 2014).

In this study the means of serum PON1 paraoxonase activity was recorded marked decrease in all CVD patients and it is more evident in the PAD group independent of the PON1 192 genotyping (QQ, QR, and RR). Similar no influence of PON1genotypes was recently reported by Martínez -Quintana et al. (2017) in patients with acute coronary syndrome (ACS). In this context, the Iraqi population presents controversial relationships regarding the 
PON1 rs 662 (Q192R) polymorphism and CVD that might be referred to small sample size, ethnic alteration, recruiting criteria, interaction between gene to gene and gene to environments (Rodríguez-Esparragón et al.,2005;Rainwater et al.,2009; Luu et al.,2011;Précourt et al.,2011). Further studies on larger sample size and including ethnicity are recommended on CVD patients. It has been concluded that the determination of serum PON1 activity is more informative than the PON1 genotype in evaluating the severity and extent of cardiovascular disease.

\section{Conclusion:-}

Reduction of PON1 activity is one of the risk factor of development of CVD . Patients who carry the RR genotyping were at high risk to develop CVD. Our results indicate that controversial relationships regarding the PON1 rs 662 (Q192R) polymorphism and CVD. Serum PON1 activity is more informative than the PON1 genotype in evaluating the severity and extent of cardiovascular disease in Iraqi patients.

List of abbreviation:-

\begin{tabular}{|l|l|}
\hline Abbreviations and Acronyms & LDL-C_ low-density lipoprotein cholesterol \\
ABCA1_ATP binding cassette transporter A1 & PON1_ paraoxonase-1 \\
ABPI_brachial pressure index & PAD_peripheral artery disease \\
BMI_body mass index & Q_ glutamine amino acid \\
CAD_coronary artery disease & R_arginine amino acid \\
CETP_cholesteryl ester transfer protein & SBP_systolic blood pressure \\
CHD_coronary heart disease & SEM_standard error of the mean \\
CK-MB_Creatine kinase -MB & TG_triglycerides \\
CVD_cardiovascular disease & VLDL_ very-low-density lipoprotein \\
DBP_dystolic blood pressure & WHO_ World Health Organization \\
HDL-C_ high-density lipoprotein cholesterol & \\
\hline
\end{tabular}

\section{Acknowledgements:-}

I would like to express my thanks to Pro Dr. Najat A. Hasan, and consultant divisor: Dr. Rafid B. Hashim for their encouragement. My gratitude to all staff of the department of chemistry and biochemistry, College of Medicine- AlNahrain University. Finally, I would like to express grateful thanks to my daughters (Sarah, Rania, and Maryam) Thamir Hadi for their assistance in writes and prints this study.

\section{References:-}

1. Adkins S, Gan KN, Mody M, La Du BN.(1991): Molecular basis for the polymorphic forms of human serum paraoxonase/ arylesterase: glutamine or arginine at position 192, for the respective A or B allozymes. Am J Hum Genet .,40:277-82.

2. Aldridge WN (1953): Serum esterases. I. Two types of esterase (A and B) hydrolysing p-nitrophenyl acetate,propionate and butyrate, and a method for their determination. Biochem J., 53: 110-117.

3. Altuner D, Suzen SH, Ates I, Koc GV, Aral Y, Karakaya A.(2011): Are PON1, Q/R 192 and M/L 55 polymorphisms risk factors for diabetes complications in a Turkish population? Clin Biochem., 44:372-376.

4. Biggs AI.(1954): A spectrophotometric determination of the dissociation constants of p-nitrophenol and papaverine. Trans Faraday Soc., 50:800-802.

5. Billecke S, Draganov D, Counsell R, Stetson P, Watson C, Hsu C, La Du BN (2000): Human serum paraoxonase (PON1) isozymes Q and R hydrolyze lactones and cyclic carbonate esters. Drug Metab Dispos, 28(11):1335-1342.

6. Blatter Garin MC, Moren X, James RW (2006): Paraoxonase-1 and serum concentrations of HDL-cholesterol and apoA-I. J Lipid Res., 47(3):515-520.

7. Bounafaa A, Berrougui H, Ghalim N, Nasser B, Bagri A, Moujahid A, Ikhlef S, Camponova P, Yamoul N, Simo OK , Essamadi A, Khalil A((2015): Association between Paraoxonase-1 (PON1) Polymorphisms and the Risk of Acute Coronary Syndrome in a North African Population. PLoS One,10 (8): e0133719.

8. Chistiakov DA, Melnichenko AA, Orekhov AN, Bobryshev YV.(2017): Paraoxonase and atherosclerosis related cardiovascular diseases. Biochimie, 132: 19-27.

9. Cohen E, Aviram M, Khatib S, Volkova N, Vaya J (2016): Human carotid atherosclerotic plaque protein(s) change HDL protein(s) composition and impair HDL anti-oxidant activity. BioFactors, 42: 115-128.

10. Costa LG, Cole TB, Jarvik GP \& Furlong CE.( 2003): Functional genomic of the paraoxonase (PON1) polymorphisms: effects on pesticide sensitivity, cardiovascular disease, and drug metabolism. Annи Rev Med., 54: 371-392. 
11. Davies HG, Richter RJ, Keifer M, Broomfield CA, Sowalla J and Furlong CE (1996): The effect of the human serum paraoxonase polymorphism is reversed with diazoxon, soman and sarin. Nat Genet 14: $334-336$.

12. Dell'Omo G, Penno G, Pucci L, Lucchesi D, Prato SD, Pedrinelli R (2014):Q192R Paraoxonase (PON)1 Polymorphism, Insulin Sensitivity, and Endothelia Function in Essential Hypertensive Men. Clin Med Insights Cardiol., 8:1-11.

13. Deakin SP, James RW (2004): Genetic and environmental factors modulating serum concentrations and activities of the antioxidant enzyme paraoxonase-1. Clin Sci.,107:435-447.

14. Du XM, Kim MJ, Hou L, Le Goff W, Chapman MJ, Van Eck M, Curtiss LK, Burnett JR, Cartland SP, Quinn CM, Kockx M, Kontush A, Rye KA, Kritharides L, Jessup W (2015): HDL particle size is a critical determinant of ABCA1-mediated macrophage cellular cholesterol export. Circ Res., 116(7): 1133-1142.

15. Durrington N.P., Mackness B., and Mackness I.M.( 2001). Paraoxonase and atherosclerosis. Arterioscler Thromb Vasc Biol., 21( 4) :473-480.

16. Friedewald WT, Levy RI, Fredrickson DS (1972): Estimation of the concentration of low-density lipoprotein cholesterol in plasma, without use of the preparative ultracentrifuge. Clin Chem.,18:499-502.

17. Gaidukov L, Rosenblat M, Aviram M, Tawfik DS (2006): The 192R/Q polymorphs of serum paraoxonase PON1 differ in HDL binding, lipolactonase stimulation, and cholesterol efflux. J Lipid Res. ,47(11):2492-502.

18. Genest J, Frohlich J, Fodor G, McPherson R (2003): Recommendations for the management of dyslipidemia and the prevention of cardiovascular disease: CMAJ.,169(9):921-924.

19. Granér M, James RW, Kahri J, Nieminen MS, Syvänne M, Taskinen M R (2006): Association of Paraoxonase-1 Activity and Concentration With Angiographic Severity and Extent of Coronary Artery Disease. Journal of the American College of Cardiology,47(12):2429-2435.

20. Hernández-Díaz Y, Tovilla-Zárate CA, Juárez-Rojop IE, González-Castro TB, Rodríguez-Pérez C, López-Narváez ML, Rodríguez-Pérez JM, Cámara-Álvarez JF (2016): Effects of paraoxonase -1 gene polymorphisms on heart diseases: Systematic review and meta-analysis of 64 case-control studies.Medicine (Baltimore)., (44):e5298.

21. Harel M, Aharoni A, Gaidukov L, Brumshtein B, Khersonsky O, Meged R, Dvir H, Ravelli RB, McCarthy A, Toker L, Silman I, Sussman JL, Tawfik DS (2004):Structure and evolution of the serum paraoxonase family of detoxifying and antiatheroscleroticenzymes. Nat Struct Mol Biol., 11(5): 412-419.

22. Ivanova EA, Orekhov AN (2016):The Role of Endoplasmic Reticulum Stress and Unfolded Protein Response in Atherosclerosis. Int J Mol Sci,17(2):193.

23. Kallel A, Sediri Y, Sbai MH, Mourali MS, Feki M, Elasmi M, Taieb SH, Sanhaji H, Souheil O,Mechmeche R, Jemaa R (2010):The paraoxonase L55M and Q192R gene polymorphisms and myocardial infarction in a Tunisian population. Clin Bio chem., 43(18): 1461-1463.

24. Kasprzak M P, Iskra M, Majewski W, Napierala B M, Gryszczynska B,Strzyzewski K, Kasprzak J (2014): PON1 status evaluation in patients with chronic arterial occlusion of lower limbs due to atherosclerosis obliterans. Archives of Medical Science, 10(6):1101-1108.

25. Kowalska K, Socha E, Milnerowicz H.(2015): The role of paraoxonase in cardiovascular diseases.Ann Clin Lab Sci.,45(2):226-33.

26. Krisch, K. (1968): Enzymatische Hydrolyse von Diäthyl-p-nitrophenylphosphat (E 600) durch menschliches Serum. Clin Chemi Lab Medi., 6(1), pp.41-45.

27. Kumar A, Mash B, Rupesinghe G.(2007): Peripheral arterial disease - high prevalence in rural black South Africans. S Afr Med J., 97(4):285-288.

28. Lakshmy R, Ahmad D, Abraham RA, Sharma M, Vemparala K, Das S, Reddy KS, Prabhakaran D (2010): Paraoxonase gene Q192R \& L55M polymorphisms in Indians with acute myocardial infarction \& association with oxidized low density lipoprotein. Indian J Med Res. ,131:522-529.

29. Lawlor DA, Day IN, Gaunt TR, Hinks LJ, Briggs PJ, Kiessling M, et al. (2004):The association of the PON1 Q192R polymorphism with coronary heart disease: findings from the British Women's Heart and Health cohort study and a meta-analysis. BMC Genet.,5:17-17.

30. Lebedy D, Kafoury M, Haleem D, Ibrahim A, Awadallah E, Ashmawy I (2014): Paraoxonase-1 gene Q192R and L55M polymorphisms and risk of cardiovascular disease in Egyptian patients with type 2 diabetes mellitus. J Diabetes Metab Disord., 13(1):124.

31. Luersen K, Schmelzer C, Boesch-Saadatmandi C, Kohl C, Rimbach G, Doring F (2011): Paraoxonase 1 polymorphism Q192R affects the pro-inflammatory cytokine TNF-alpha in healthy males. BMC ResNotes 4: 141.

32. Luu HN, Kingah PL, North K, Boerwinkle E, Volcik KA ( 2011): Interaction of folate intake and the paraoxonase Q192R polymorphism with risk of incident coronary heart disease and ischemic stroke: the atherosclerosis risk in communities study. Ann Epidemiol., 21(11):815-823.

33. Mackness MI, Arrol S, Durrington PN ( 1991): Paraoxonase prevents accumulation of lipoperoxides in low-density lipoprotein. FEBS Lett. ,286(1-2):152-154. 
34. Mackness MI, Arrol S, Abbott CA, Durrington PN.( 1993): Is paraoxonase related to atherosclerosis. Chem Biol Interact, 87(13):161-171.

35. Mackness MI, Mackness B, Durrington PN, Connelly PW, Hegele RA (1996): Paraoxonase: biochemistry, genetics and relationship to plasma lipoproteins. Curr Opin Lipidol .,7(2):69-76.

36. Mackness M, Mackness B( 2014): Current Aspects of Paraoxonase-1 Research. In: Tsugikazu Komoda.. The HDL Handbook: Biological functions and clinical implications. $2^{\text {nd }}$ ed Academic Press, Chapter (11) pages 273-291.

37. Martínez-Quintana E, RodríguezGonzález F, Medina-Gil JM, Garay-Sánchez P, Tugores A (2017): Paraoxonase- 1 (Q192R) gene polymorphism, coronary heart disease and the risk of a new acute coronary event. Clin Investig Arterioscler. , 29(1):1-6.

38. Norgren, L,Hiatt, W R, Dormandy, J A,Nehler, M R,Harris, K A,Fowkes, F G R(2007): Inter-Society Consensus for the Management of Peripheral Arterial Disease ( TASC II ). J Vasc Surg,45(1):s5-s67

39. Ombres D, Pannitteri G, Montali A, Candeloro A, Seccareccia F, Campagna F, Cantini R, Campa PP, Ricci G and Arca M (1998) : The gln-Arg192 polymorphism of human paraoxonase gene is not associated with coronary artery disease in italian patients. Arterioscler Thromb Vasc Biol 18: 1611-1616.

40. Paapstel, K.Zilmer, M.Eha, J.Tootsi, K.Piir, A.Kals, J.(2016): Association Between Fibulin-1 and Aortic Augmentation Index in Male Patients with Peripheral Arterial Disease. Eur J Vasc Endovasc Surg ,51(1); 76-82.

41. Précourt LP, Amre D, Denis MC, Lavoie JC, Delvin E, Seidman E, Levy E.(2011): The three-gene paraoxonase family:physiologic roles, actions and regulation. Atherosclerosis , 214(1): 20-36.

42. Primo-Parma SL, Sorenson RC, Teiber J, La Du BN (1996): The human serum paraoxonase/arylesterase gene (PON1) is one member of a multigene family. Genomics 33, 498-509.

43. Rainwater DL, Rutherford S, Dyer TD, Rainwater ED, Cole SA, Vandeberg JL, Almasy L, Blangero J, Maccluer JW, Mahaney MC ( 2009): Determinants of variation in human serum paraoxonase activity. Heredity (Edinb),102:147154.

44. Rodríguez-Esparragón F, Rodríguez-Pérez JC, Hernández-Trujillo Y, Macías-Reyes A, Medina A, Caballero A, Ferrario CM (2005):Allelic variants of the human scavenger receptor class B type 1 and paraoxonase 1 on coronary heart disease: genotypephenotype correlations. Arterioscler Thromb Vasc Biol.,25:854-860.

45. Rozek LS, Hatsukami TS, Richter RJ, Ranchalis J, Nakayama K, McKinstry, LA, Gortner DA , Boyko E, Schellenberg GD, Furlong CE, Jarvik GP (2005): The correlation of paraoxonase (PON1) activity with lipid and lipoprotein levels differs with vascular disease status. Journal of Lipid Research, 46(9):1888-1895.

46. Roth GA, Forouzanfar MH, Moran AE, Barber R, Nguyen G, Feigin VL, Naghavi M, Mensah GA, Murray CH JL (2015): Demographic and epidemiologic drivers of global cardiovascular mortality. N Engl J Med .,372:1333-1341.

47. Scherrer DZ, de Souza Zago V H,Vieira IC, Parra ES, Panzoldo NB, Alexandre F, Secolin R, Baracat J,Rocha Quintao EC, de Faria, EC (2015): p.Q192R SNP of PON1 seems not to be Associated with Carotid Atherosclerosis Risk Factors in an Asymptomatic and Normolipidemic Brazilian Population Sample. Arquivos Brasileiros De Cardiologia, 105(1):45-52.

48. Sentí M, Tomás M, Marrugat J, Elosua R, Investigators R (2001): Paraoxonase1-192 Polymorphism Modulates the Nonfatal Myocardial Infarction Risk Associated With Decreased HDLs. Arterioscler Thromb Vasc Biol., 21:415-420.

49. Thiruvoipati T, Kielhorn CE, Armstrong EJ (2015):Peripheral artery disease in patients with diabetes : Epidemiology,mechanisms, and outcomes. World J Diabetes ,6(7):961-969.

50. Zargari M, Sharafeddin F, Mahrooz A, Alizadeh A, Masoumi P (2016): The common variant Q192R at the paraoxonase 1 (PON1) gene and its activity are responsible for a portion of the altered antioxidant status in type 2 diabetes. Exp Biol Med (Maywood)., 241(14):1489-96.

51. World Health Organization(WHO): Regional Office for Southeast Asia. Hypertension fact sheet. Last accessed at http://www.searo.who.int/linkfiles/non_communicable_diseases_hypertension-fs.pdf . April 2012.

52. World Health Organization (WHO):Cardiovascular Diseases (CVDs), Factsheet: (Accessed on 2015 May 02). Available online: http://www.who.int/mediacentre/factsheets/fs317/en/. 